\title{
RECENTLY RECOGNIZED TYPES OF SOME HOMOPTERA DESCRIBED BY DR. ASA FITCH ${ }^{1}$
}

\author{
By JefFrey K. BARneS \\ Biolological Survey \\ New York State Museum \\ The State Education Department \\ Albany, NY 12230
}

\begin{abstract}
Dr. Asa Fitch (1809-1879) proposed 165 new species and subspecies names in the Homoptera. They are taxonomically distributed as follows: Cicadidae (2), Membracidae (21), Cicadellidae (34), Cercopidae (9), Delphacidae (2), Derbidae (7), Cixiidae
\end{abstract} (2), Achilidae (2), Issidae (2), Psyllidae (9), Aleyrodidae (1), Aphididae (52), Adelgidae (2), Phylloxeridae (4), Diaspididae (5), and Coccidae (11). He proposed the names in print from 1851 to 1872, mainly in his Homoptera catalogue (1851) and the Transactions of the New York State Agricultural Society.

Dr. Fitch never designated types for his new species and subspecies. However, he did label nearly all of his specimens with individual numbers. He recorded these numbers consecutively in four individual registers, along with collecting dates, localities, and other pertinent information. Label numbers in black ink written on white paper are recorded in one register of specimens from New York State. Label numbers in black ink crossed with one or two red lines and written on white paper are recorded in a second register of specimens from New York State. One red line indicates a number less than 10,000, and two red lines indicate a number to which 10,000 should be added. Label numbers in red ink written on white paper are recorded in a third register that lists specimens from elsewhere in North America. These three registers are in the possession of the New York State Museum. The fourth register, owned by the Museum of Science, successor to the Boston Society of Natural History, lists specimens from elsewhere in the world. The corresponding labels are written in black ink on colored papers. Dr. Fitch also kept individual sheets of notes on every species of which

I Published as New York State Museum Journal Series No. 426.

Manuscript received by the editor February 20, 1984. 
he was aware. If he had specimens of any one species, he recorded the specimen label numbers along with collection data on the appropriate manuscript sheet. Most of these notes are in the New York State Museum. Many of the Homoptera notes are in the Smithsonian Institution Archives and the files of the United States National Museum aphid collection.

According to the International Code of Zoological Nomenclature, the type series of a species or subspecies consists of all the specimens on which its author bases the species (Article 72b). The closest available approximation to a type series for a species or subspecies authored by Dr. Fitch consists of those specimens that can be proven, through a perusal of his registers and notes, to have been in his collection before or during the year in which the relevant species or subspecies name was first made available. In the introduction to his Homoptera catalogue, dated February 22, 1851, Dr. Fitch acknowledged the loan of all of Dr. Thaddeus William Harris's collection of Homoptera. In a letter to Dr. Harris, Dr. Fitch stated that he was forwarding copies of his Homoptera catalogue. He also stated that it would be a pleasure for him to add specimens from his collection to Dr. Harris's collection. ${ }^{2}$ That letter is dated March 1-4, 1851.

The T. W. Harris insect collection at the Museum of Comparative Zoology, Harvard University, is segregated from the main collection. In it, several of Dr. Fitch's specimens are readily recognized by the label style and handwriting (Fig. 1). Some of these are specimens of species that Fitch described in his Homoptera catalogue. Those that were in Dr. Fitch's possession before February 28, 1851 (the earliest publication date for the Homoptera catalogue that can be demonstrated by evidence) can be considered types, but they have never been recognized as such. In most cases, these specimens are part of a syntype series, and other specimens can be found in the New York State Museum (McCabe and Johnson 1980) or the United States National Museum. In these cases, lectotypes should be designated if that has not already been done. Other specimens in the Harris collection are the only known extant specimens from the Fitch collection that Dr. Fitch considered to be representatives of certain species that he authored.

${ }^{2}$ Fitch to Harris, 1-4 March, 1851; Museum of Comparative Zoology, Harvard University. 


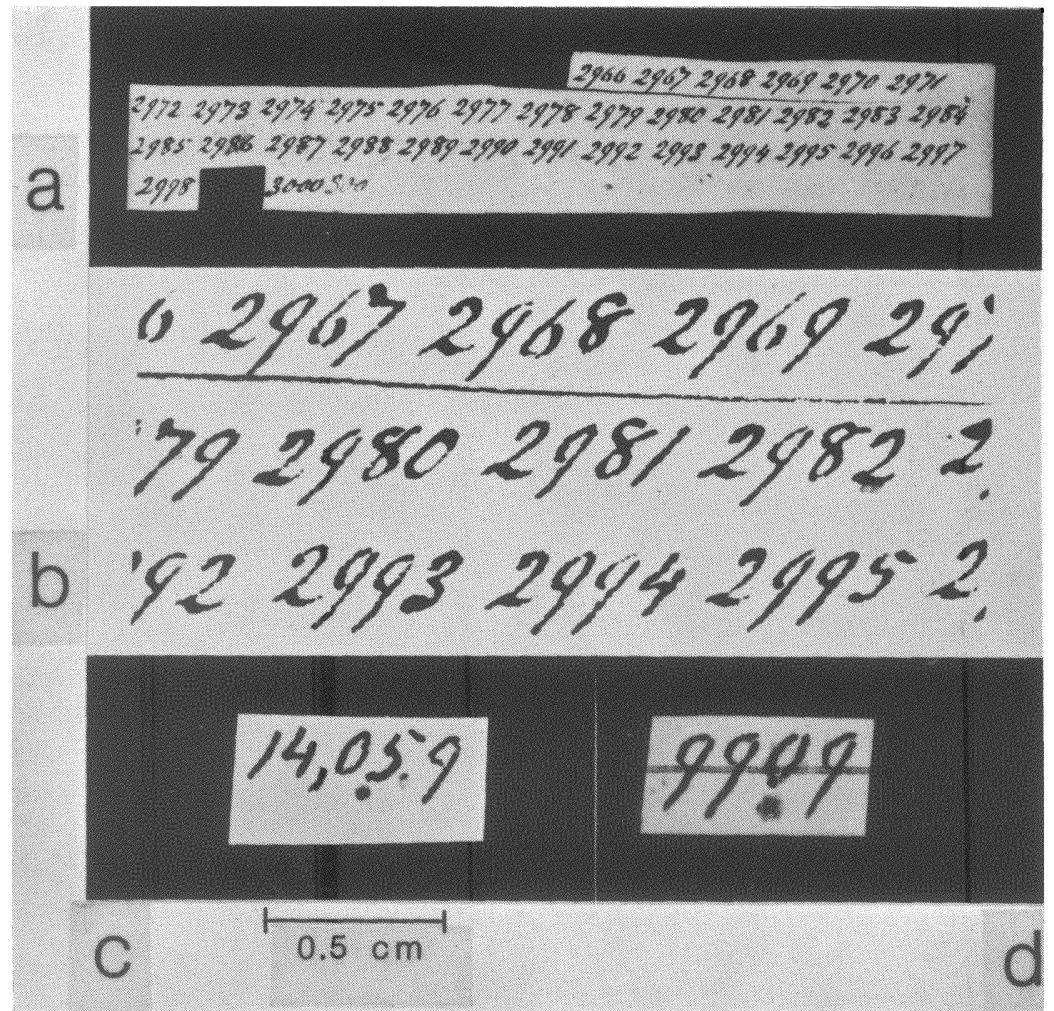

Fig. 1. Dr. Asa Fitch's handwriting and style of insect labels. a, uncut strip of labels; b, close-up view of a section of a; c, New York insect label 14,059, black ink on white paper; d, New York insect label $* 9909$, black ink on white paper, crossed with one red line. Labels $\mathrm{c}$ and $\mathrm{d}$ same scale.

The following list contains brief descriptions of specimens from Dr. Fitch's collection that can now be found in the Harris collection. Generic and specific names are spelled exactly as they were in the original publications. Only specimens of species authored by Dr. Fitch are listed. The label numbers that are preceeded by one or two asterisks correspond with specimen labels that are written in black ink on white paper and crossed with one or two red lines, respectively. A summary of collecting data, derived from Dr. Fitch's registers and notes, accompanies each description of a specimen. 


\section{Membracidae}

Uroxiphus caryae Fitch, 1851:52.

*3992, Greenwich, NY, 24.viii.1846.

*3997, Greenwich, NY, 24.viii.1846.

Tragopa dorsalis Fitch, 1851:52.

**134, Salem, NY, 25.vii.1851.

**137, Salem, NY, 25.vii.1851.

Cyrtoisa fenestrata Fitch, 1851:49.

*6927, Long Island, NY, 1847.

\section{Cicadellidae}

Idiocerus alternatus Fitch, 1851:59.

*8665, Salem, NY, 7.v.1851.

*8828, Salem, NY, 10.v.1851.

*9075, Salem, NY, 19.v.1851.

Helochara communis Fitch, 1851:56.

*8761, Salem, NY, 10.v.1851

Amblycephalus curtisii Fitch, 1851:61.

12,702, Salem, NY, 22.xi.1850.

Gypona flavilineata Fitch, 1851:57.

*6304, Salem, NY, 10.ix.1847.

Jassus fulvidorsum Fitch, 1851:62.

*6178, Salem, NY, 21.viii.1847.

Amblycephalus melsheimerii Fitch, 1851:61.

*4911, Salem, NY, 5.vii.1847.

Athysanus minor Fitch, 1851:60.

*4869, Salem, NY, 5.vii.1847.

Athysanus nigrinasi Fitch, 1851:61.

*2983, Jackson, NY, 16.vi.1846.

Aulacizes noveboracensis Fitch, 1851:56.

*9936, Salem, NY, 12.vii.1851.

Idiocerus pallidus Fitch, 1851:59.

*6059, Salem, NY, 19.viii.1847.

*9834, Salem, NY, 5.vii.1851.

Empoa querci Fitch, 1851:63.

13,299, Stillwater, NY, vii.1848.

Amblycephalus sayii Fitch, 1851:61.

*9234, Salem, NY, 30.v.1851. 
Bythoscopus strobi Fitch, 1851:58.

*9397, Salem, NY, 5.vi.1851.

Erythroneura tricincta Fitch, 1851:63.

*6402, Salem, NY, 10.ix.1847.

Bythoscopus unicolor Fitch, 1851:58.

2021, Tullehassie, AR [Tullahasee, OK], viii.1851.

*4909, Salem, NY, 5.vii.1847.

Athysanus variabilis Fitch, 1851:60

*9822, Salem, NY, 5.vii.1851.

Pediopsis viridis Fitch, 1851:59.

*9836, Salem, NY, 5.vii.1851.

**153, Salem, NY, 25.vii.1851.

Erythroneura vulnerata Fitch, 1851:62.

*6467, Salem, NY, 10.ix.1847.

*6621, Greenwich, NY, 20.ix.1847.

*6629, Greenwich, NY, 20.ix.1847.

\section{Cercopidae}

Clastoptera testacea Fitch, 1851:53.

*5322, Salem, NY, 23.vii.1847.

\section{Delphacidae}

Delphax arvensis, 1851:46.

12,358, Salem, NY, 3.vi.1847.

Delphax dorsalis Fitch, 1851:46.

*8500, Salem, NY, 26.iv.1851.

*8578, Salem, NY, 29.iv.1851.

\section{Cixildae}

Cixius pini Fitch, 1851:45.

474, Winhall, VT, 17.vi.1847.

ISSIDAE

Bruchomorpha dorsata Fitch, 1857:396.

1555, Tullehassie, AR [Tullahassee, OK], 1.vi.1851.

Naso robertsonii Fitch, 1857:396.

1776, Tullehassie, AR [Tullahassee, OK], vii.1851. 


\section{Psyllidae}

Psylla carpini Fitch, 1851:64.

*9224, Salem, NY, 30.v.1851.

\section{Aphididae}

Aphis crataegifoliae Fitch, 1851:66.

*9287, Salem, NY, 2.vi.1851.

Aphis populifoliae Fitch, 1851:66.

*9294, Salem, NY, 5.vi.1851.

*9298, Salem, NY, 5.vi.1851.

Eriosoma pyri Fitch, 1851:68.

*4053, Salem, NY, 10.xi.1846.

*4054, Salem, NY, 10.xi.1846.

Aphis rudbeckiae Fitch, 1851:66.

11,715, Salem, NY, 13.vii.1846.

11,717, Salem, NY, 13.vii.1846.

Dr. Fitch described six new genera, 85 new species, and five new subspecies in his Homoptera catalogue. The New York State Museum's collection still contains type specimens of 60 of the species and subspecies. The remainder have been considered destroyed (Lintner 1893, McCabe and Johnson 1980). The specimens that Dr. Fitch listed in his catalogue were numbered 609-874, and he tagged the specimens with numbered labels printed expressly for that purpose (Funkhouser 1915). These numbers bear no relationship to the numbers in Dr. Fitch's manuscript species notes or specimen registers. In the United States National Museum there are six specimens labelled in Dr. Fitch's handwriting with three digit numbers that correspond with those in his Homoptera catalogue. They are two specimens of Psyllidae, Livia femoralis Fitch (838) and L. vernalis Fitch (836), and four specimens of Aphididae, Aphis betulaecolens Fitch (848), A. cerasicolens Fitch (841), A. berberidis Fitch (842), and $A$. sambucifoliae Fitch (850). Specimen 842 is also labelled Aphis pinicolens Fitch, but not in Fitch's handwriting. A seventh specimen in the USNM - a specimen of Aphis cornifoliae Fitch-is labelled "846 Fitch," "Type," and "Female," corresponding with the information given in Fitch's catalogue, but these labels are not in Fitch's handwriting. Two more specimens of Aphididae, Lachnus abietis Fitch (854) and L. alnifoliae Fitch (857), 
are described in Smith and Parron's list of North American Aphididae (1978) as "nearly destroyed, in USNM," but I have been unable to locate them.

\section{Literature Cited}

Fiтch, A.

1851. Catalogue with references and descriptions of the insects collected and arranged for the State Cabinet of Natural History. Pages 43-69 in Fourth annual report of the Regents of the University, on the condition of the State Cabinet of Natural History, and the historical and antiquarian collection, annexed thereto. Made to the Senate, January 14, 1851. Albany. $146 \mathrm{pp}$.

[1857]. Third report on the noxious and other insects of the State of New York. Transactions of the New York State Agricultural Society 16(1856): 315-490.

FUnKHOUSER, W. D.

1915. Types of Fitch's species of Membracidae. Bulletin of the Brooklyn Entomological Society 10: 45-50.

Lintner, J. A.

1893. Catalogue of the known Homoptera of the State of New York in 1851. Annual Report of the New York State Museum 46: 381.

MCCABe, T. L., AND L. M. Johnson.

1980. Catalogue of the types in the New York State Museum insect collection. New York State Museum Bulletin 434: 1-38.

Smith, C. F., and C. S. Parron.

1978. An annotated list of Aphididae (Homoptera) of North America. North Carolina Agricultural Experiment Station Technical Bulletin 255: 1-428. 

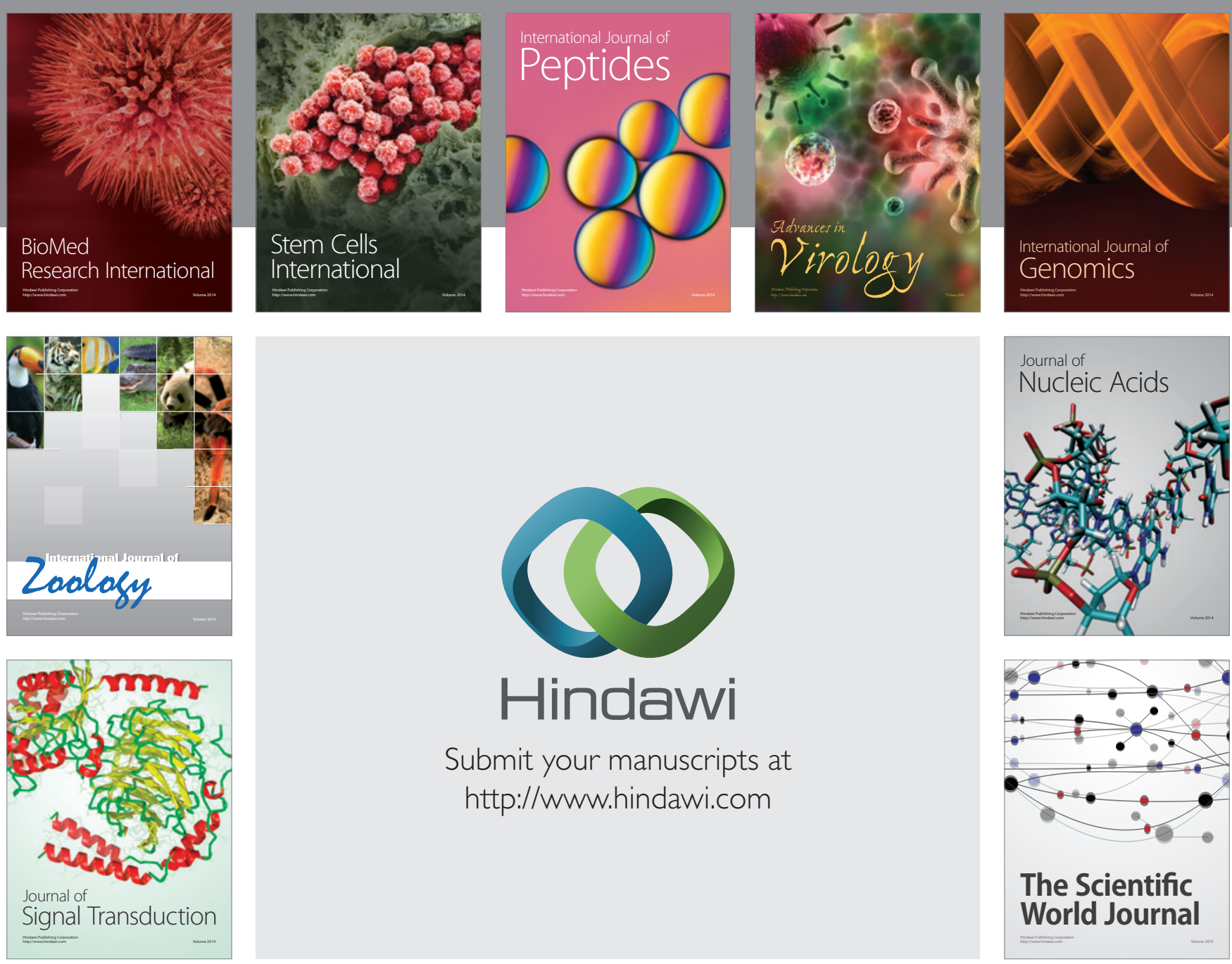

Submit your manuscripts at

http://www.hindawi.com
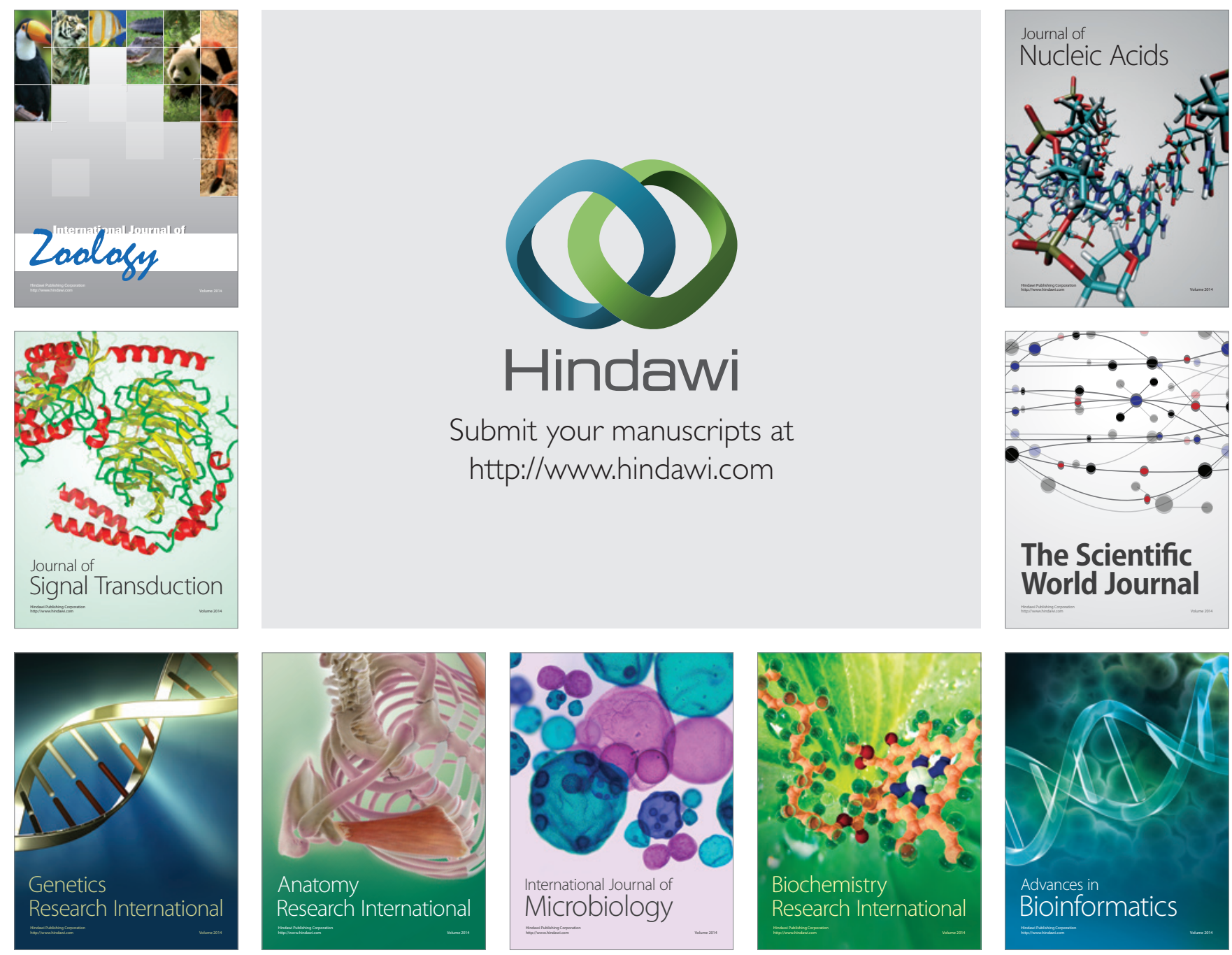

The Scientific World Journal
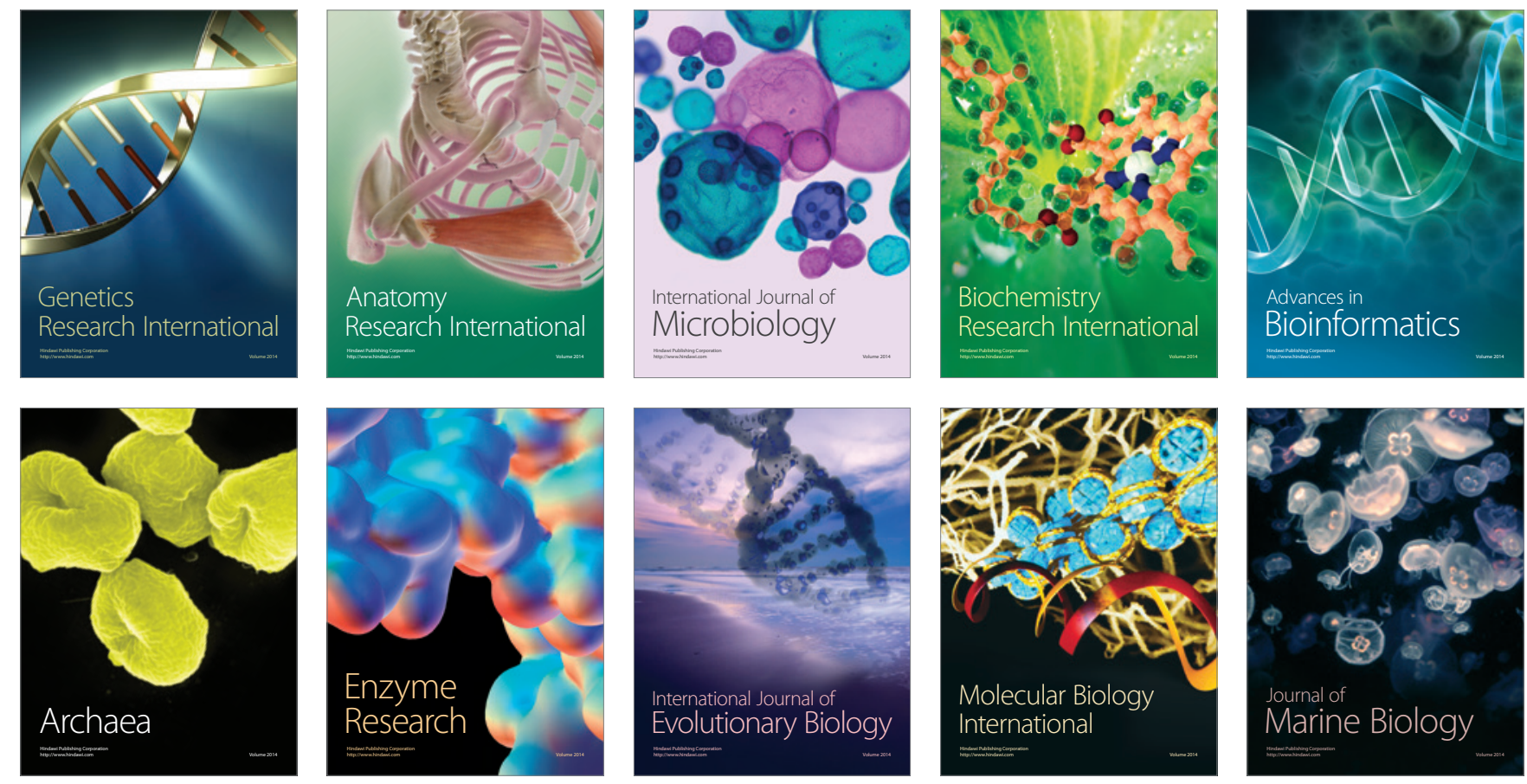